\title{
Dietary treatment for obesity reduces BMI and improves eating psychopathology, self-esteem and mood
}

Citation for published version (APA):

Werrij, M. Q., Mulkens, S., Hospers, H. J., Smits-de Bruyn, Y., \& Jansen, A. T. M. (2008). Dietary treatment for obesity reduces BMI and improves eating psychopathology, self-esteem and mood. Netherlands Journal of Psychology, 64(1), 8-14. https://doi.org/10.1007/BF03076404

Document status and date:

Published: 01/01/2008

DOI:

10.1007/BF03076404

Document Version:

Publisher's PDF, also known as Version of record

\section{Document license:}

Taverne

Please check the document version of this publication:

- A submitted manuscript is the version of the article upon submission and before peer-review. There can be important differences between the submitted version and the official published version of record. People interested in the research are advised to contact the author for the final version of the publication, or visit the DOI to the publisher's website.

- The final author version and the galley proof are versions of the publication after peer review.

- The final published version features the final layout of the paper including the volume, issue and page numbers.

Link to publication

\footnotetext{
General rights rights.

- You may freely distribute the URL identifying the publication in the public portal. please follow below link for the End User Agreement:

www.umlib.nl/taverne-license

Take down policy

If you believe that this document breaches copyright please contact us at:

repository@maastrichtuniversity.nl

providing details and we will investigate your claim.
}

Copyright and moral rights for the publications made accessible in the public portal are retained by the authors and/or other copyright owners and it is a condition of accessing publications that users recognise and abide by the legal requirements associated with these

- Users may download and print one copy of any publication from the public portal for the purpose of private study or research.

- You may not further distribute the material or use it for any profit-making activity or commercial gain

If the publication is distributed under the terms of Article $25 \mathrm{fa}$ of the Dutch Copyright Act, indicated by the "Taverne" license above, 


\section{Dietary treatment for obesity reduces $\mathrm{BMI}$ and improves eating psychopathology, self-esteem and mood}

Marieke Q. Werrij, Sandra Mulkens, Harm J. Hospers, Yvonne Smits-de Bruyn and Anita Jansen

Objectives: In the present study, the hypothesis was tested that a regular dietary treatment for obesity that is primarily directed at decreasing weight will also decrease concerns about shape, weight and eating, will reduce binge eating, and will improve mood and self-esteem. Moreover, we investigated whether a group treatment and an individual treatment were equally effective.

Method: Fifty-four obese participants followed either a group treatment $(n=31)$ or an individual treatment $(n=23)$ provided by dieticians.

Results: The data showed that overall, BMI, weight concerns and depressive symptoms decreased and self-esteem increased. The percentage of bingers decreased marginally significantly. For dietary restraint, eating concerns and shape concerns group treatment led to greater changes than individual treatment.

Conclusion: Although the dietary treatment was not aimed at changing psychological characteristics, patients significantly improved on measures of eating-related and general psychopathology. (Netherlands Journal of Psychology, 64, 8-14.)

Keywords: dietary treatment; obesity; eating psychopathology; general psychopathology

The prevalence of overweight and obesity is increasing worldwide (Visscher, Kromhout \& Seidell, 2002; Wadden, Brownell \& Foster, 2002). Currently, behavioural treatments focusing on

\footnotetext{
Maastricht University

Correspondence to: Marieke Werrij, Department of Work and Social Psychology (UNS 5), Faculty of Psychology, Maastricht University, PO Box 616, NL 6200 MD Maastricht, e-mail: m.werrij@psychology.unimaas.nl

Received 18 September 2007; revision accepted 12 October 2007
}

energy intake and physical exercise are a standard treatment for obesity (Wilson, 1994), and most research has concentrated on the effectiveness of these programmes (e.g. Garner \& Wooley, 1991; Jeffery, Epstein, Wilson, Drewnowski, Stunkard \& Wing, 200o; Wilson, 1994). The effectiveness of conventional dietetic counselling aiming to improve dietary patterns has been investigated less extensively, but research suggests that these counselling programmes produce short-term weight losses (Katz et al., 2002; Pritchard, Hyndman \& Taba, 1999; Van den Borne, 
Geertsma \& Westmaas Jes, 1988), blood pressure improvements (Pritchard et al,, 1999) and even reductions in compulsive eating behaviour, depression and anxiety (Van den Borne et al., 1988).

Randomised clinical trials of dietary treatments mainly focus on weight reduction (Katz et al., 2002; Pritchard et al., 1999; Torgerson, Agren \& Sjostrom, 1999; Torgerson, Lissner, Lindroos, Kruijer \& Sjostrom, 1997), leaving psychological variables aside. However, several studies suggest that obesity is associated with psychological problems, such as concerns about appearance (Fairburn \& Cooper, 1993; Marcus, Smith, Santelli \& Kaye, 1992; Sullivan, 2001; Wilfley, Schwartz, Spurrell \& Fairburn, 2000), a depressed mood (Kalarchian, Wilson, Brolin \& Bradley, 1998; Musante, Costanzo \& Friedman, 1998; Polivy \& Herman, 1992; Porzelius, Houston, Smith, Arfken \& Fisher, 1995; Sbrocco, Nedegaard, Stone \& Lewis, 1999; Tanco, Linden \& Earle, 1998; Telch \& Agras, 1994; Troisi, Scucchi, San Martino, Montera, d'Amore \& Moles, 2001; Venditti, Wing, Jakicic, Butler \& Marcus, 1996), and low self-esteem (de Zwaan et al., 1994; Quinn \& Crocker, 1999; Striegel Moore, Wilson, Wilfley, Elder \& Brownell, 1998). Furthermore, a substantial minority of the obese population reports periods of overeating that can be described as binge eating (e.g. Jansen, 1998; Johnsen, Gorin, Stone \& le Grange, 2003).

Recent cognitive-behavioural models of obesity state that concerns about shape, weight and eating, and self-esteem play an important role in the maintenance of obesity (Cooper \& Fairburn, 2001; Nauta, Hospers, Kok \& Jansen, 2000), and cognitive therapy - directed at identifying and changing those dysfunctional concerns - is put forward as a promising treatment option in obesity. Regular dietary treatments aim to change dietary patterns, and are not specifically directed at changing psychological characteristics. Interestingly, however, psychological outcomes are rarely studied after those treatments. Is it necessary to treat obese people with psychotherapeutic interventions in order to change concerns about shape, weight and eating, depressed mood and low self esteem? Or is regular dietary treatment sufficient to change these psychological states? Concerns about appearance are not so strange in overweight people. So, possibly, weight reduction is accompanied by decreased appearance-related concerns and improved mood and self-esteem as well. We hypothesised that a regular dietary treatment for obesity that is primarily directed at decreasing weight, also decreases concerns about shape, weight and eating, reduces binge eating, and improves mood and self-esteem, without psychological intervention. Because dietary treatments in field settings are provided in groups but also individually, it is of practical interest to test whether group and individual treatments are equally effective.

\section{Method}

\section{Participants}

The participants were 59 overweight and obese people who registered for a regular dietary treatment by a dietician. Main inclusion criteria were BMI $>25$ and age above 18 years. Five persons were excluded from the analyses because they had too many missing values (>10\%). The final study sample thus included 54 overweight/obese people.

\section{Treatment}

Treatment, in groups or individually, was carried out by dieticians experienced in the treatment of obesity. Participants enlisted for either treatment modality by choice. Both treatments aimed at weight losses of $0.5 \mathrm{~kg}$ per week (total weight loss 5 to $10 \%$ ). The group treatment included ten weekly 75 -minute sessions. In the individual treatment, nine 15-minute meetings were offered after one 6o-minute intake assessment. The frequency of these individual meetings varied depending on the patient's agenda. In addition to nutritional counselling, both treatments focussed on a regular eating pattern, setting realistic goals, identifying high-risk situations, selfmonitoring and motivation to exercise. In the individual treatment nutritional counselling was personally tailored as is standard practice.

\section{Procedure}

Pre-treatment questionnaires were mailed to the participants and collected at the first appointment by the dietician. Post-treatment questionnaires were handed out after the last treatment session. Questionnaires were sent back to the university in prepaid envelopes.

\section{Measures}

\section{Main outcome measures}

Weight and height (BMI) were collected from dieticians' patient records. Specific eating psychopathology was measured with the EDE-Q (Eating Disorder Examination - Questionnaire; Fairburn \& Beglin, 1994), a 36-item questionnaire that measures concerns about shape, weight and eating and binge eating. Subscale scores for shape, weight and eating concerns and restraint ranged between $o$ and 6 . A higher score indicates more severe eating psychopathology. Binge eating was measured as a dichotomous variable (binger / non-binger). Self-esteem was measured with the RSE (Rosenberg Self-Esteem Scale; Rosenberg, 1965). The RSE measures global self-esteem and consists of ten items. A higher score indicates a more positive selfesteem. Mood was measured with the BDI (Beck Depression Inventory; Beck, Ward, Mendelson, Mock \& Erbaugh, 1961). The BDI measures the severity of depressive symptoms and consists of 
21 items. One item about weight loss was excluded from analyses and the sum of the remaining 20 items was calculated. A higher score indicates more depressive symptoms.

\section{Demographics and motivation}

Motivational level was measured by five items, for example 'At the moment, losing weight is one of the most important things in my life' or 'I intend to maintain the new eating pattern I will learn for the rest of my life' $(1=$ totally agree, $5=$ totally disagree). The items (Cronbach's alpha = 0.73) were averaged to compose a motivation scale. In addition, sex and age were measured.

\section{Statistical analyses}

Missing items were replaced by the mean score on the remaining items of the scale (EDE-Q, RSE , BDI). Data were analysed in 2 (time: pretreatment vs. post-treatment) X 2 (group: individual vs. group treatment) repeated-measures ANOVAs. The results section is structured according to our hypotheses. First, main effects of time are reported to test our main hypothesis. Second, time $\mathrm{x}$ group interactions are reported to investigate differences between the treatments (individual and group). For significant interactions, paired sample $t$-tests were conducted per group. For BMI, group differences were not examined due to a limited post-treatment sample in the individual treatment $(n=5)$. Therefore for BMI, a paired sample $t$-test was performed to investigate the main effect of time. McNemar's test for paired proportions was used to test overall changes in the percentages of bingers. Differences between the treatments concerning changes in the percentage of bingers were investigated by $\chi^{2}$ analyses. Correlation analyses provided insight into the relation between changes in $\mathrm{BMI}$ on the one hand and changes on specific eating psychopathology (EDE-Q), self-esteem (RSE) and mood (BDI) on the other hand. Results with $p$ values $<0.05$ are considered statistically significant; $p$ values $<0.10$ (but $>0.05$ ) are considered marginally significant.

\section{Results}

\section{Participant characteristics}

Before treatment, participants in the two treatments were comparable on age, sex, motivation, and main outcome measures (all $p$ values $n s$ ), although EDE-Q restraint scores tended to be higher in the individual treatment (tables 1 and 2).

\section{Main hypothesis}

In support of our main hypothesis, main effects of time were found for BMI, EDE-Q weight concerns, RSE, and BDI (table 2). After treatment, BMI, weight concerns and depressive symptoms decreased, and self-esteem increased. Main effects of time were also significant for EDE-Q restraint and EDE-Q shape concerns. However, these main effects were qualified by a significant time $\mathrm{x}$ group interaction for EDE-Q restraint and a marginally significant interaction for EDE-Q shape concerns (described below). The main effect of time for EDE-Q eating concerns was not significant. The percentage of bingers decreased marginally significantly.

\section{Differences between the treatments}

Time $x$ group interactions were significant for EDE-Q restraint and EDE-Q eating concerns (table 2). Restraint scores remained the same after individual treatment, but increased after group treatment. Eating concerns remained the same after individual treatment, but decreased after group treatment. For EDE-Q shape concerns the time $\mathrm{x}$ group interaction was marginally significant. Although means suggest that both treatments reduced shape concerns, this effect was only significant for the group treatment. The time $x$ group interaction was not significant for EDE-Qweight concerns, self-esteem, and mood. The main effect of group was not significant for any of the outcome measures (all F's $<1)$. Changes in the percentage of bingers did not differ significantly between the treatments.

\begin{tabular}{l|c|c|}
\hline Table 1 & Age, sex and pre-treatment motivation per treatment condition. & \\
& $\begin{array}{c}\text { Individual treatment } \\
(n=23)\end{array}$ & $\begin{array}{c}\text { Group treatment } \\
(n=31)\end{array}$ \\
\hline Age (SD) & $45(16.89)$ & $45(10.99)$ \\
\hline Sex & & $94 \%$ \\
\hline - Female & $87 \%$ & $6 \%$ \\
\hline - Male & $13 \%$ & $1.70(0.66)$
\end{tabular}

Note: the differences in age, sex and pre-treatment motivation were not significant. 


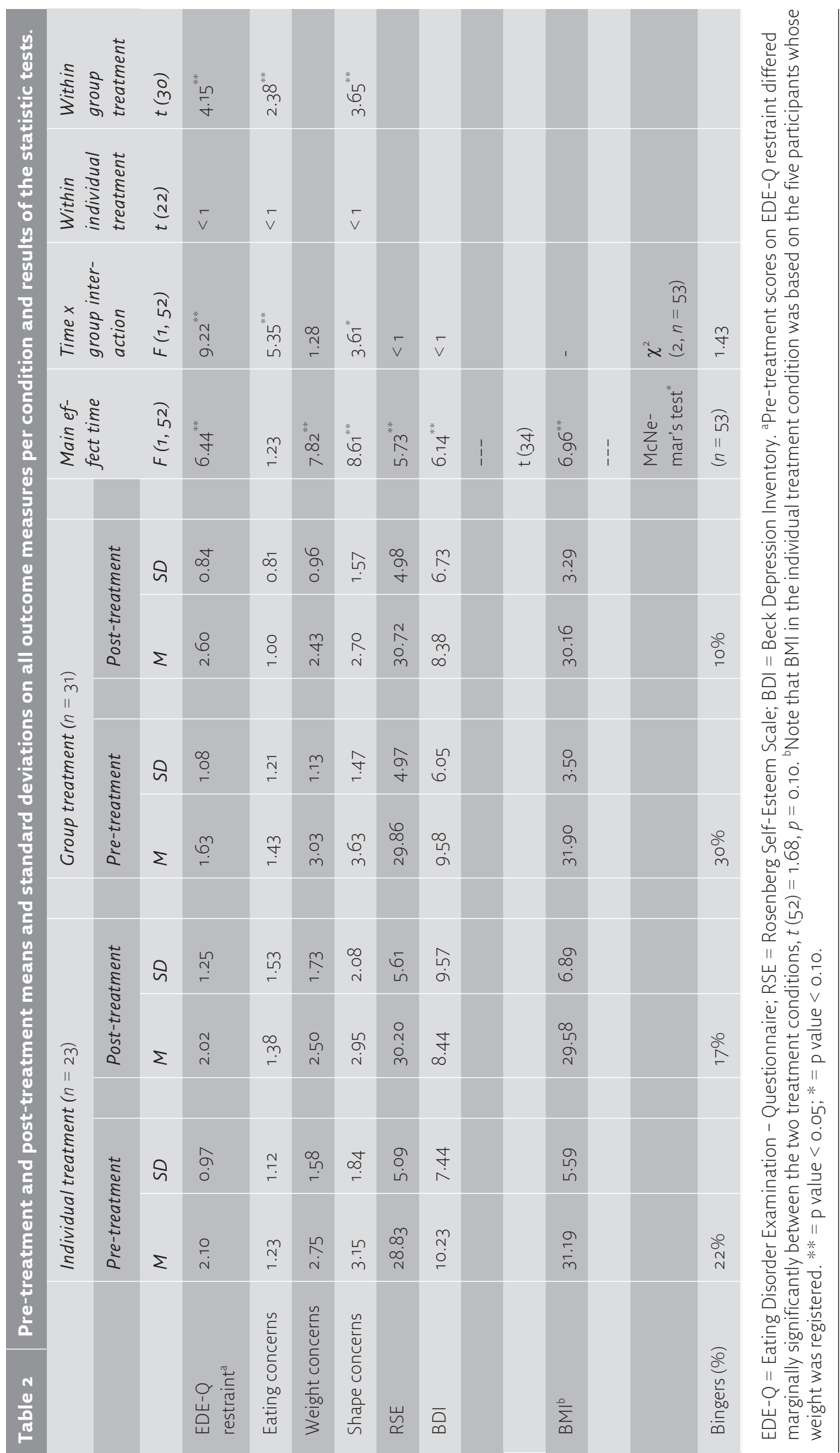




\section{Correlation analyses}

Pre-treatment to post-treatment changes in BMI were significantly related to changes in shape concerns, $r=0.43, p<0.01$. Participants with a greater decrease in BMI after treatment reported a greater decrease in shape concerns. Larger BMI reductions tended to be related to a greater increase in restraint, $r=-0.32, p<0.06$ and to a greater decrease in weight concerns, $r=0.32, p<$ o.o6. None of the other correlations were significant.

\section{Discussion}

In this study, we investigated whether a regular dietary treatment for obesity, directed at weight reduction, also improves eating psychopathology, self-esteem and mood. Overall, the dietary treatment led to significant weight loss, decreased weight concerns and depressive symptoms, and increased self-esteem. The percentage of bingers tended to decrease. Differences between the treatments emerged for restraint, eating concerns and shape concerns. After group treatment, restraint increased and eating concerns decreased whereas after individual treatment, these factors did not change. Furthermore, although means suggest that both treatments reduced shape concerns, group treatment tended to be more effective in reducing these concerns. In reducing concerns about eating and shape, group treatment at least tended to be superior.

BMI decreased significantly. Although there were not enough BMI data in the individual treatment to study treatment differences, the data show that overall, participants lost weight. Reductions in BMI were significantly correlated to decreased concerns about shape, and tended to be related to increased restraint and decreased concerns about weight. Bearing in mind that BMI data were only available for part of the sample, these data suggest that even modest weight losses are related to a decrease in concerns about weight and shape. Surprisingly, no evidence was found in the present study for a correlation between weight loss on the one hand and improvements in self-esteem or mood on the other hand. Clearly, these factors were unrelated.

Interestingly, the present study shows that dietary treatment, directed at reducing weight, is also successful in changing eating-related and general psychopathology, although these psychological factors did not receive attention in the treatments. Do these data suggest that recently promoted treatments that consider there is an important role for cognitions in the maintenance of obesity, and that promote cognitive therapy in treating obesity (Cooper \& Fairburn,
2001; Nauta et al, 2000), are superfluous? Do they suggest that concerns about appearance, mood and self-esteem are only an artefact of being obese, and that dietary treatment is sufficient in effectively improving these measures of psychological well-being? We think they do not. Although this might be the case concerning the short-term effectiveness of dietary treatments, the question remains whether participants will maintain their weight in the long run. It is now well known that the long-term effectiveness of behavioural programmes for obesity is disappointing (Garner \& Wooley, 1991; Jeffery et al., 2000; Wilson, 1994). Presumably, regaining weight brings back concerns about appearance and depressive symptoms, and decreases selfesteem. The development of treatments that help people maintain their weight remains very important. By directly targeting those dysfunctional cognitions that are assumed to play a role in maintaining obesity, cognitive therapy might be a promising means to improve current treatments (Cooper \& Fairburn, 2001; Nauta et al, 2000).

Restraint scores increased after group treatment. This might be considered a negative finding by some authors, as according to restraint theory, dieting precedes binge eating (Polivy \& Herman, 1985; 1993). However, support for this model is inconsistent (Presnell \& Stice, 2003; Stice, 2002). Studies that manipulated caloric intake in the natural environment (i.e., participants were assigned to a low-calorie diet) even found a decrease of eating psychopathology over time (Stice, 2002). Accordingly, the present short-term data suggest that concerns about eating, weight and shape decreased after treatment. The percentage of bingers tended to decrease. Although the reduction in the percentage of bingers was only marginally significant, the hypothesis that dieting increases the risk for the onset of bulimic pathology was certainly not supported by the data. Being on a diet, or being restrained, may thus be very functional in a population of overweight people as it produces (short-term) weight loss and decreases eating psychopathology. A long-term follow-up is needed to study how restraint scores and eating psychopathology develop in the longer run.

For restraint, eating concerns and shape concerns, the group treatment led to larger changes than the individual treatment. Possibly, the group treatment was more effective for these measures because it provided peer support. From a review conducted by Hogan, Linden and Najarian (2002) it was concluded that social support interventions are useful in areas that ranged from cancer and weight loss to parenting skills and birth preparation.

This study investigated weight loss related improvements on eating psychopathology, self- 
esteem and mood after a regular dietary treatment. The study was therefore performed in a field setting, which was accompanied by several methodological shortcomings. A first limitation is the lack of a long-term follow-up. Furthermore, assignment to treatment condition could not occur at random, there was no no-treatment control group, and our sample size was small. Finally, being dependent on questionnaires, binge eating could not be investigated optimally (Fairburn \& Beglin, 1994; Kalarchian, Wilson, Brolin \& Bradley, 200o). Our study could not be designed as an RCT for practical reasons. Therefore, our results need to be interpreted with caution. Because a no-treatment control group was lacking, it is not certain whether the positive effects of time reflect a pure effect of treatment. However, (cognitive) behavioural programmes were superior to no-treatment control groups in the treatment of binge eating (e.g., Peterson et al., 1998; Wilfley et al., 1993) and dietary counselling was superior to a control group of no counselling in the treatment of overweight (Pritchard et al., 1999). Moreover, the non-random allocation to group might have caused unmeasured factors to confound the pure effects of treatment. To overcome these shortcomings and to confirm the results, this research should be repeated as an RCT including more participants and a long-term follow-up.

\section{Conclusions}

In conclusion, the present data show that a standard dietary treatment for obesity - directed at reducing weight - also improved psychological well-being; weight concerns decreased, and selfesteem and mood increased. In reducing eating and shape concerns, group treatment was more effective than individual treatment. Interestingly, although the dietary treatment did not intend to change psychological characteristics, patients significantly improved on measures of eating related and general psychopathology.

\section{Acknowledgments}

This study was financed by the Netherlands Organisation for Health Research and Development (ZonMw). The authors would like to thank all the dieticians and the secretaries of the Groene Kruis Zorg [Green Cross Care] in Maastricht, the Netherlands, for their help in collecting the data and Anne Roefs for useful comments on an earlier draft.

\section{References}

Beck, A.T., Ward, C.H., Mendelson, M., Mock, J. \& Erbaugh, J. (1961). An inventory for measuring depression. Archives of General Psychiatry, 4, 561-571.

Cooper, Z. \& Fairburn, C.G. (2001). A new cognitive behavioural approach to the treatment of obesity. Behavior Research and Therapy, 39, 499-511.

De Zwaan, M., Mitchell, J.E., Seim, H.C., Specker, S.M., Pyle, R.L., Raymond, N.C. \& Crosby, R.B. (1994). Eating related and general psychopathology in obese females with binge eating disorder. International Journal of Eating Disorders, 15, 43-52.

Fairburn, C.G. \& Beglin, S.J. (1994). Assessment of eating disorders: Interview or self-report questionnaire? International Journal of Eating Disorders, 16, 363-370.

Fairburn, C.G. \& Cooper, Z. (1993). The Eating Disorder Examination (12th edition). In: C.G. Fairburn (Ed.). Binge eating: Nature, assessment, and treatment (pp. 317-36o). New York, NY: Guilford Press.

Garner, D.M. \& Wooley, S.C. (1991). Confronting the failure of behavioral and dietary treatments for obesity. Clinical Psychology Review, 11, 729-780.

Hogan, B.E., Linden, W.L. \& Najarian, B. (2002). Social support interventions: Do they work? Clinical Psychological Review, 22, 381-440.

Jansen A. (1998). Eating Disorders. In: A.S. Bellack \& M. Hersen (Eds). Comprehensive Clinical Psych- ology (pp. 649-667). Oxford: Elsevier Science Limited, Pergamon Press.

Jeffery, R.W., Epstein, L.H., Wilson, G.T., Drewnowski, A., Stunkard, A.J. \& Wing R.R. (2000). Long-term maintenance of weight loss: Current status. Health Psychology, 19 (Suppl 1), 5-16.

Johnsen, L.A.P., Gorin, A., Stone, A.A. \& le Grange, D. (2003). Characteristics of binge eating among women in the community seeking treatment for binge eating or weight loss. Eating Behaviors, 3, 295-305.

Kalarchian, M.A., Wilson, G.T., Brolin, R.E. \& Bradley, L. (2000). Assessment of eating disorders in bariatric surgery candidates: Self-report questionnaire versus interview. International Journal of Eating Disorders, 28, 465-469.

Kalarchian, M.A., Wilson, G.T., Brolin, R.E. \& Bradley, L. (1998). Binge eating in bariatric surgery patients. International Journal of Eating Disorders, 23, 89-92.

Katz, D.L., Chan, W., Gonzalez, M., Larson, D., Nawaz, H., Abdulrahman, M. \& Yeh, M.C. (2002). Technical skills for weight loss: preliminary data from a randomized trial. Preventive Medicine,34, 6o8-15.

Marcus, M.D., Smith, D., Santelli, R. \& Kaye, W. (1992). Characterization of eating disordered be- 
havior in obese binge eaters. International Journal of Eating Disorders, 12, 249-255.

Musante, G.J., Costanzo, P.R. \& Friedman, K.E. (1998). The comorbidity of depression and eating dysregulation processes in a diet-seeking obese population: A matter of gender specificity. International Journal of Eating Disorders, 23, 65-75.

Nauta, H., Hospers, H., Kok, G. \& Jansen, A. (2000). A comparison between a cognitive and behavioral treatment for obese binge eaters and obese nonbinge eaters. Behavior Therapy, 31, 441-461.

Peterson, C. B., Mitchell, J.E., Engbloom, S., Nugent, S., Mussell, M.P. \& Miller, J.P. (1998). Group cognitive-behavioral treatment of binge eating disorder: A comparison of therapist-led versus self-help formats. International Journal of Eating Disorders, 24, 125-136.

Polivy, J. \& Herman, C.P. (1985). Dieting and binging: A causal analysis. American Psychologist, 40, 193-201.

Polivy, J. \& Herman, C.P. (1993). Etiology of binge eating: Psychological mechanisms. In: C.G. Fairburn (Ed.). Binge eating: Nature, assessment, and treatment (pp. 173-205). New York, NY: Guilford Press.

Polivy, J. \& Herman, C.P. (1992). Undieting: A program to help people stop dieting. International Journal of Eating Disorders, 11, 261-268.

Porzelius, L. K., Houston, C., Smith, M., Arfken, C. \& Fisher, E. (1995). Comparison of a standard behavioral weight loss treatment and a binge eating weight loss treatment. Behavior Therapy, 26, 119134.

Presnell, K. \& Stice, E. (2003). An experimental test of the effect of weight-loss dieting on bulimic pathology: Tipping the scales in a different direction. Journal of Abnormal Psychology, 112, 166-170.

Pritchard, D.A., Hyndman, J. \& Taba, F. (1999). Nutritional counselling in general practice: a cost effective analysis. Journal of Epidemiology and Community Health, 53, 311-6.

Quinn, D.M. \& Crocker, J. (1999). When ideology hurts: Effects of belief in the Protestant ethic and feeling overweight on the psychological wellbeing of women. Journal of Personality and Social Psychology, 77, 402-414.

Rosenberg, M. (1965). Society and the adolescent selfimage. Princeton, NJ: Princeton University Press. Sbrocco, T., Nedegaard, R.C., Stone, J.M. \& Lewis, E.L. (1999). Behavioral Choice Treatment Promotes Continuing Weight Loss; Preliminary Results of a Cognitive-Behavioral Decision-Based Treatment for Obesity. Journal of Consulting and Clinical Psychology, 67, 260-266.

Stice, E. (2002). Risk and maintenance factors for eating pathology: A meta-analytic review. Psychological Bulletin, 128, 825-848.

Striegel Moore, R.H., Wilson, G.T., Wilfley, D.E., Elder, K.A. \& Brownell, K.D. (1998). Binge eating in an obese community sample. International Journal of Eating Disorders, 23, 27-37.
Sullivan, K.A. (2001). The clinical features of binge eating disorder and bulimia nervosa: What are the differences? Canadian Journal of Counselling, 35, 315-328.

Tanco, S., Linden, W. \& Earle, T. (1998). Well-being and morbid obesity in women: A controlled therapy evaluation. International Journal of Eating Disorders, 23, 325-339.

Telch, C.F. \& Agras, W.S. (1994). Obesity, binge eating and psychopathology: Are they related? International Journal of Eating Disorders, 15, 53-61.

Torgerson, J.S., Agren, L. \& Sjostrom, L. (1999). Effects on body weight of strict or liberal adherence to an initial period of VLCD treatment. A randomised, one-year clinical trial of obese subjects. International Journal of Obesity, 23, 190-197.

Torgerson, J.S., Lissner, L., Lindroos, A. K., Kruijer, H. \& Sjostrom, L. (1997). VLCD plus dietary and behavioural support versus support alone in the treatment of severe obesity. A randomised twoyear clinical trial. International Journal of Obesity, 21, 987-94.

Troisi, A., Scucchi, S., San Martino, L., Montera, P., d'Amore, A. \& Moles, A. (2001). Age specificity of the relationship between serum cholesterol and mood in obese women. Physiology and Behavior, 72 , 409-413.

Van den Borne, H.W., Geertsma, F. \& Westmaas Jes, M.M. (1988). Effecten van een nieuwe groepsbehandeling voor dikke vrouwen. / Effectiveness of a new group treatment for obese women. Gedrag and Gezondheid: Tijdschrift voor Psychologie en Gezondheid, 16, 108-116.

Venditti, E.M., Wing, R.R., Jakicic, J.M., Butler, B.A. \& Marcus, M.D. (1996). Weight cycling, psychological health, and binge eating in obese women. Journal of Consulting and Clinical Psychology, 64, 400-405.

Visscher, T.L., Kromhout, D. \& Seidell, J.C. (2002). Long-term and recent time trends in the prevalence of obesity among Dutch men and women. International Journal of Obesity, 26, 1218-24. Wadden, T.A., Brownell, K.D. \& Foster, G.D. (2002). Obesity: Responding to the global epidemic. Journal of Consulting and Clinical Psychology, 70, 510-525. Wilfley, D.E., Agras, W.S., Telch, C.F., Rossiter, E.M., Schneider, J.A., Golomb Cole, A. et al. (1993). Group cognitive-behavioral therapy and group interpersonal psychotherapy for the nonpurging bulimic individual: A controlled comparison. Journal of Consulting and Clinical Psychology, 61, 296-305.

Wilfley, D. E., Schwartz, M. B., Spurrell, E. B. \& Fairburn, C.G. (2000). Using the Eating Disorder Examination to identify the specific psychopathology of binge eating disorder. International Journal of Eating Disorders, 27, 259-269.

Wilson, G.T. (1994). Behavioral treatment of obesity: Thirty years and counting. Advances in Behaviour Research and Therapy, 16, 31-75. 